\title{
Epidemics of Ray Blight on Pyrethrum are Linked to Seed Contamination and Overwintering Inoculum of Phoma ligulicola var. inoxydabilis
}

\author{
Sarah J. Pethybridge, David H. Gent, and Frank S. Hay
}

First author: Botanical Resources Australia-Agricultural Services Pty. Ltd., Ulverstone, Tasmania, 7315, Australia; second author: United States Department of Agriculture-Agricultural Research Services, Forage Seed and Cereal Research Unit, and Oregon State University, Department of Botany and Plant Pathology, Corvallis 97331; and third author: Tasmanian Institute of Agricultural Research, University of Tasmania-Cradle Coast campus, Burnie, 7320, Australia. Accepted for publication 11 April 2011.

\begin{abstract}
Pethybridge, S. J., Gent, D. H., and Hay, F. S. 2011. Epidemics of ray blight on pyrethrum are linked to seed contamination and overwintering inoculum of Phoma ligulicola var. inoxydabilis. Phytopathology 101: 1112-1121.

Ray blight, caused by Phoma ligulicola var. inoxydabilis, is the most damaging disease of pyrethrum (Tanacetum cinerariifolium) in Australia. Data collected from 72 plots in commercial pyrethrum fields since 2001 to 2009 revealed substantial annual variations in isolation frequency of the pathogen during semidormancy of the crop in autumn and winter. Isolation frequency of the pathogen during this time and subsequent outbreaks of ray blight in spring were similar across the eight production regions where sampling was conducted, and isolation frequency of the pathogen was linearly correlated $(r=0.88 ; P<0.0001)$ with subsequent defoliation severity when plants commenced growth in spring. Isolation frequency and defoliation severity also were correlated with the incidence of seed infested with P. ligulicola var. inoxydabilis $(r=0.71$ and 0.44 ,

constructed using logistic regression. A model based solely on isolation frequency of the pathogen over autumn and winter correctly predicted epidemic development in $92 \%$ of fields. Another model utilizing the incidence of infested seed and rain-temperature interactions in early autumn (austral March and April) and late winter (austral June and July) had similar predictive ability ( $92 \%$ accuracy). Path analysis modeling was used to disentangle interrelationships among the explanatory variables used in the second logistic regression model. The analysis indicated that seedborne inoculum of $P$. ligulicola var. inoxydabilis contributes indirectly to ray blight defoliation severity through directly increasing overwintering frequency of the pathogen. Autumn and fall weather variables were modeled to have indirect effects on defoliation severity through increasing overwintering success of the pathogen but also direct effects on defoliation severity. Collectively, the analyses point to several critical stages in the disease cycle that can be targeted to minimize the probability of regional epidemics of ray blight in this perennial pathosystem.
\end{abstract} respectively; $P<0.0001$ in both correlations). Highly accurate risk algorithms for the occurrence of severe epidemics of ray blight were

Pyrethrum (Tanacetum cinerariifolium) is a member of the Asteraceae family that is produced solely for insecticidal pyrethrins, which are produced within the achenes of the flowers. Central to the economic viability of the highly mechanized production system in Australia is the use of seed as the planting material, which was first implemented commercially in 1998. Prior to the use of seed, pyrethrum fields were established using "splits", which involved the removal of larger plants, splitting these into smaller vegetative propagules, and then manually planting (19). Since the introduction of seed, the crop is typically sown from July to September and the first harvest is then conducted $\approx 18$ months thereafter in the following midsummer. Following first harvest, the plant habit then becomes perennial, resulting in leaf regrowth following harvest in autumn, a semidormant period over winter, and a flush of stem and leaf growth in spring. Maximum stem height is achieved within 6 weeks of the initiation of stem growth (approximately early October), and flowers are produced in a synchronous flush beginning in early November. Ideally, the field may sustain three to four harvests before replanting, each harvest being conducted on an annual basis.

Corresponding author: S. J. Pethybridge;

E-mail address: spethybridge@ pyrethrum.com.au

doi:10.1094/PHYTO-03-11-0067

(C) 2011 The American Phytopathological Society
Additional keywords: crop loss, disease management.
Ray blight, caused by Phoma ligulicola var. inoxydabilis (syn. Stagonosporopsis ligulicola var. inoxydabilis) (2), is the most damaging disease occurring in Australian pyrethrum fields. The disease was considered a minor and only sporadic problem on flowers since its first observation in Australia in 1995 (35). Ray blight appeared in a severe form which caused dieback of developing stems in early spring 1999 (28-30). Severe disease outbreaks were prevalent and complete crop loss was common in many fields $(29,35)$. The occurrence of the severe form of ray blight coincided directly with the establishment of pyrethrum fields with seed. Disease management now relies heavily on regular application of fungicides, with sprays commencing in spring with resumption of shoot growth $(29,31,33)$.

Since the initial epidemic in 1999, P. ligulicola var. inoxydabilis has been found to be seedborne and, in some years, the incidence of seed infested with the fungus can be $>20 \%$ (32). This has led to conjecture over the potential contribution of infested seed as a source of primary inoculum for this disease. In an effort to reduce the potential contribution of primary seedborne inoculum, pyrethrum seed crops and seed are now routinely treated with fungicides (32). Spatial modeling of ray blight epidemics suggests very short-range spread of inoculum from lesions on leaves in spring, presumably rain-splashed conidia originating from a local source $(26,34)$. This provides circumstantial evidence that fungicide treatment of the seed is not completely effective at reducing this primary inoculum source to a negligible incidence 
(S. J. Pethybridge, unpublished data). The dominant role of a local source of inoculum is also suggested by the apparent absence of perithecia and ascospores of the teleomorph Didymella ligulicola in pyrethrum fields (26). Moreover, the contribution of pseudosclerotia has also been discounted due to the relatively short survival times in soil (3 to 6 months) compared with the recommended rotation between pyrethrum fields of 3 years (29). In contrast, in the closely related disease chrysanthemum ray blight, caused by $P$. ligulicola var. ligulicola, the teleomorph is frequently observed in diseased tissue and ascospores are the dominant source of inoculum for the flower blight phase of the disease (3-5).

Previous temporal modeling of ray blight epidemics conducted during the early spring period depicted a rapid increase in defoliation severity best described by Gompertz and logistic models (26), which can correspond to a polycyclic disease (20). P. ligulicola var. inoxydabilis has also been found associated with necrotic lesions on leaves during autumn and winter (30). Despite this, the relative contribution of this potential overwintering inoculum to epidemic development in spring, to that of infested seed, remains speculative. For example, it has been assumed that infested seed leads to diseased seedlings with necrotic lesions over autumn and winter which, in turn, leads to defoliation and dieback of stems in spring, which may also contribute to direct loss of flowers over spring and summer.

Site-specific risk models reported for ray blight have focused on modeling the relationships between edaphic factors and meteorological variables on epidemic severity in spring (27). In a model developed for predicting defoliation severity risk in October, the time most closely correlated with yield loss (25), the most important variables were associated with rain events in the previous 14 to 30 days, plant growth in September, and defoliation severity during September. Hence, the importance of a combination of host availability (measured by stem height) and inoculum availability in October (inferred from defoliation severity in September) is emphasized in this model (27).

In this research, we sought to better describe the interrelationships between factors leading to occurrence of $P$. ligulicola var. inoxydabilis on foliage during autumn and winter months, and their association with the severity of subsequent ray blight outbreaks in spring, prior to the first harvest of the field. From these associations, we also sought to develop improved risk algorithms for estimating the severity of ray blight epidemics.

\section{MATERIALS AND METHODS}

Field locations and data collection. In each of 9 years (2001 to 2009), eight pyrethrum fields approaching first harvest were arbitrarily selected from the main pyrethrum-production districts on the northwest coast of Tasmania. Thus, in total, 72 fields sampled. Fields included in the study were contained within a $100-\mathrm{km}$ area between the eastern boundary of UTM coordinate 55G 4628995435784 and western boundary coordinate 55G 3801465466162 , and no further than $15 \mathrm{~km}$ inland from the coast. Within each field, one plot ( $10 \mathrm{~m}$ long by $24 \mathrm{~m}$ wide) was established that did not receive any fungicides for the management of ray blight. The remainder of the field received the industryrecommended fungicide program, which varied over this period but included the fungicides difenoconazole, azoxystrobin, chlorothalonil, cyprodinil, and boscalid $(15,31,33)$.

Fungal isolations and disease intensity measurements. The incidence of $P$ ligulicola var. inoxydabilis in the seed used to establish each field was estimated 4 months prior to planting using methods described previously (32). In brief, 10 non-surfacesterilized seeds from each seed lot were placed directly on water agar (WA) in each of 20 petri dishes $(n=200)$ and incubated in the dark at $20^{\circ} \mathrm{C}$ for 21 days. The incidence of $P$. ligulicola var. inoxydabilis was determined from observations of individual seeds made at $\times 63$ magnification. The identity of these isolates were confirmed by subculturing $20 \%$ of isolates to potato dextrose agar (PDA) (Amyl Laboratories, Melbourne, Australia), malt extract (malt-extract oxoid L39 and oxoid agar No. 1; Acumedia Manufacturers Inc., Baltimore, MD), and oatmeal agars (Amyl Laboratories) for identification $(2,8,40)$. Prior to planting, all seed was fungicide-treated using the industry standard protocol (32).

Isolations were made from individual necrotic lesions on each of 20 leaves from each field at monthly intervals during May to August in each year prior to the first harvest of the fields. This technique was used to quantify the relative proportion of necrotic lesions caused by $P$. ligulicola var. inoxydabilis compared with other fungal pathogens and abiotic factors. At each sampling time, the leaves were systematically selected from plants across a diagonal transect within each of the plots. Leaves were collected on the same day from all eight fields sampled within a year. Leaves collected from each field were surface sterilized in $1 \%$ sodium hypochlorite for $2 \mathrm{~min}$, then rinsed three times in sterile distilled water. Small pieces $\left(<2 \mathrm{~mm}^{3}\right)$ were excised from junctions of the healthy and necrotic tissue. These pieces were placed on WA in petri dishes and incubated at $18^{\circ} \mathrm{C}$ in the dark for 5 days. The hyphal tip of the resultant mycelia was then placed on PDA. The presence of $P$. ligulicola var. inoxydabilis was confirmed by subculturing onto PDA, malt extract, and oatmeal agars for identification $(2,8,40)$. These data were used to calculate the area under the isolation frequency curve (AUIFC) to express overwintering inoculum as a single value (20).

Defoliation severity in October ( $\approx 2$ months prior to first harvest of the field) was also assessed by destructively sampling a total of 60 stems collected along three equally spaced horizontal transects in each plot. In the laboratory, the height of each stem and the point to which the leaves were either completely necrotic or abscised (from the base of the plant) was measured within $24 \mathrm{~h}$ of collection. Defoliation severity was then calculated as the point to defoliation divided by total stem height $\times 100$. This single time point was selected for disease assessments because previous investigations of disease intensity and yield loss relationships have found that maximum disease intensity occurs in October $(25,26)$. At this time, when defoliation severity is $>38.2 \%$, the incidence of flowers with ray blight increases linearly, which significantly reduces one of the key components of pyrethrin yield (25). In the analyses described below, this threshold was rounded up to $40 \%$, a more conservative threshold, for simplicity and also pedagogic reasons (27).

Weather data. The centroid of each pyrethrum field was recorded with a handheld GPS unit (GPS eTrex Vista HCx; Garmin International Inc., Olathe, KS), and was used as a geospatial reference for obtaining interpolated site-specific daily weather data (temperature and rainfall) from the Queensland Department of Natural Resources and Mines Data Drill algorithm (12). The precision of interpolated temperature and rainfall data has been reported as $0.5^{\circ} \mathrm{C}$ and $1 \mathrm{~mm}$, respectively, at a spatial resolution of $\approx 5 \mathrm{~km}^{2}(11,12,39)$. The errors associated with the use of interpolated weather data compared with on-site meteorological information in northern Tasmania have been reported previously (27).

Preliminary analysis of variables related to overwintering inoculum and ray blight outbreaks. Scatterplots were created for the weather variables and inoculum factors, with AUIFC or defoliation severity in October as the dependent variables. Temperature and wetness typically are the weather parameters most closely correlated with the degree of infection by foliar fungal pathogens $(10,14)$, including $P$. ligulicola var. inoxydabilis (27). Thus, we first investigated the relationship of the response variables to the independent variables of monthly rain and accumulated degree-days during each month from January to July. Simple degree-days were calculated as (daily high temperature + daily low temperature $) / 2-5^{\circ} \mathrm{C}$. The base temperature of 
$5^{\circ} \mathrm{C}$ was selected because it is approximately the minimum temperature for pyrethrum development (7) and also representative of the lower temperature threshold for growth of $P$. ligulicola (21-23).

Independent variables correlating highly with isolation frequency or defoliation severity were selected, and outliers from these correlations were examined to design other variables that could explain deviations from the average tendencies. Nonlinear regression models were constructed to describe the relationships between incidence of infested seed, AUIFC, and defoliation severity. Models describing an exponential rise to a maximum were fitted in Sigma Plot (version 11; Systat Software Inc., San Jose, CA). As a second step to identify variables associated with defoliation severity in the spring, the distribution of individual weather and inoculum variables in fields with severe and nonsevere epidemics of ray blight were compared. As explained above, previous research (25) described a threshold defoliation severity of $\approx 40 \%$, above which there is a linear increase in the incidence of flowers with ray blight. This defoliation threshold can be considered a metric of epidemic severity or one form of an economic injury level. We coded fields as " 1 " if defoliation was $>40 \%$ and " 0 " otherwise, and then compared whether the distribution of weather and (incidence of infested seed and overwintering inoculum frequency on leaves) differed between these groups using the nonparametric Kolmogorov-Smirnov (KS) test. The analysis was conducted using the NPAR1WAY procedure in SAS (version 9.2; SAS Institute, Cary, NC) with Monte Carlo estimation to derive exact $P$ values.

Logistic regression modeling of severe ray blight epidemics. Following the preliminary analysis, the original weather variables and other new variables constructed after inspection of outliers were evaluated as predictors of severe ray blight epidemics using logistic regression. We again coded fields as " 1 " if defoliation was $>40 \%$ and " 0 " otherwise, and fitted two logistic regression models based on the autumnal and winter weather and inoculum variables. The first model included all of the variables included in
Table 1 (except defoliation severity), including the AUIFC. Conducting repeated isolations over time is very laborious and resource intensive, and impractical to implement on a large scale. In the second model fitting, we sought a model that did not include isolation frequency data as a predictor variable in an effort to produce a model with readily measurable input variables that could be more easily implemented.

In both model-fitting processes, automated stepwise selection was utilized to construct preliminary models (24). Candidate models were evaluated based on Akaike's Information Criterion (AIC) and the Hosmer and Lemeshow goodness-of-fit test. Classification accuracy was summarized as overall accuracy, sensitivity, and specificity of the models. Sensitivity and specificity can be considered special cases of positive and negative prediction accuracy (20). In this context, sensitivity is the proportion of fields where severe ray blight epidemics occurred (termed "cases") that were classified correctly. Specificity is the proportion of fields where severe epidemics did not occur (termed "controls") that were classified correctly. Parsimonious models with low AIC values, high prediction accuracy, adequate fit diagnostics, and biologically logical combinations of variables were selected as the final models. Logistic regression models were fit and examined using the LOGISTIC procedure and its options in SAS.

Path analysis. Determining how weather variables, seed infestation, and overwintering inoculum frequency of $P$. ligulicola var. inoxydabilis interact to affect defoliation in spring is not possible with simple regression models because the variables could have both direct and indirect effects on overwintering of the pathogen or disease development in spring. An example of the latter could be that weather influences host growth and susceptibility to defoliation, with or without effecting overwintering success of the pathogen. Path analysis offers a means to characterize and quantify complex interactions of variables and test various models of how risk factors may lead to defoliation in spring. The analysis begins by developing a "path diagram" to

TABLE 1. Associations between inoculum and weather variables and defoliation severity of pyrethrum caused by ray blight in Tasmania, Australia

\begin{tabular}{|c|c|c|c|c|c|c|c|c|}
\hline \multirow[b]{2}{*}{ Variable } & \multicolumn{4}{|c|}{ Defoliation severity $(\%)^{\mathrm{a}}$} & \multicolumn{2}{|c|}{ Seed infestation $(\%)^{\mathrm{b}}$} & \multicolumn{2}{|c|}{ Isolation frequency ${ }^{c}$} \\
\hline & $K S^{d}$ & $P$ value & $r$ & $P$ value & $r$ & $P$ value & $r$ & $P$ value \\
\hline Seed infestation & 0.29 & $<0.0001$ & 0.59 & $<0.0001$ & $\cdots$ & & $\ldots$ & $\ldots$ \\
\hline Isolation frequency & 0.44 & $<0.0001$ & 0.88 & $<0.0001$ & 0.71 & $<0.0001$ & $\ldots$ & $\ldots$ \\
\hline \multicolumn{9}{|l|}{ Rain (mm) } \\
\hline Sum & 0.17 & 0.029 & 0.16 & 0.183 & -0.18 & 0.135 & 0.17 & 0.162 \\
\hline January & 0.13 & 0.146 & -0.12 & 0.315 & -0.16 & 0.177 & 0.03 & 0.822 \\
\hline February & 0.12 & 0.201 & -0.18 & 0.132 & 0.08 & 0.483 & -0.23 & 0.049 \\
\hline March & 0.31 & $<0.0001$ & 0.38 & 0.001 & 0.28 & 0.016 & 0.40 & 0.001 \\
\hline April & 0.20 & 0.003 & 0.27 & 0.021 & -0.17 & 0.159 & 0.16 & 0.185 \\
\hline May & 0.18 & 0.019 & -0.49 & $<0.0001$ & -0.35 & 0.002 & -0.37 & 0.002 \\
\hline June & 0.29 & $<0.0001$ & 0.50 & $<0.0001$ & 0.12 & 0.335 & 0.44 & $<0.0001$ \\
\hline July & 0.10 & 0.464 & 0.02 & 0.855 & -0.19 & 0.111 & -0.09 & 0.464 \\
\hline \multicolumn{9}{|l|}{ Degree-days ${ }^{\mathrm{e}}$} \\
\hline January & 0.14 & 0.080 & 0.09 & 0.461 & 0.22 & 0.068 & 0.11 & 0.345 \\
\hline February & 0.18 & 0.014 & -0.11 & 0.379 & -0.05 & 0.656 & 0.01 & 0.911 \\
\hline March & 0.07 & 0.768 & -0.18 & 0.129 & -0.14 & 0.228 & -0.19 & 0.104 \\
\hline April & 0.12 & 0.180 & 0.15 & 0.222 & 0.00 & 0.989 & 0.11 & 0.344 \\
\hline May & 0.13 & 0.131 & 0.06 & 0.633 & -0.21 & 0.083 & 0.01 & 0.951 \\
\hline June & 0.24 & 0.0002 & 0.43 & 0.000 & 0.17 & 0.159 & 0.29 & 0.013 \\
\hline July & 0.19 & 0.009 & 0.51 & $<0.0001$ & 0.59 & $<0.0001$ & 0.48 & $<0.0001$ \\
\hline \multicolumn{9}{|c|}{$\log ($ sum of rain $) \times$ degree-days } \\
\hline March-April & 0.32 & $<0.0001$ & 0.40 & 0.001 & 0.06 & 0.619 & 0.35 & 0.003 \\
\hline June-July & 0.24 & $<0.0001$ & 0.59 & $<0.0001$ & 0.37 & 0.001 & 0.47 & $<0.0001$ \\
\hline
\end{tabular}

a Defoliation severity data were collected from plots where fungicides were not applied in eight pyrethrum fields during each year from 2001 to 2009 ( $n=72$ fields).

${ }^{\mathrm{b}}$ Seed infestation is the incidence $(\%)$ of the pyrethrum seed used to establish the fields that was monitored for ray blight prior to fungicide treatment of the seed.

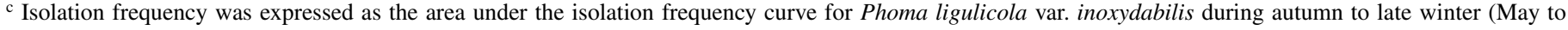
August).

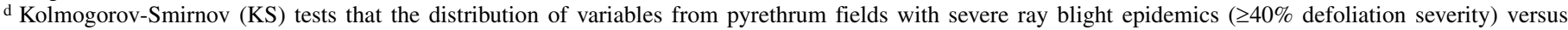
those with nonsevere epidemics are similar; see text for details.

${ }^{\text {e }}$ Cumulative monthly degree-days (base $5^{\circ} \mathrm{C}$ ). 
present a structured hypothesis of how system components combine to affect an "endogenous" (analogous to a response variable in linear regression) variable. A path diagram can be construed as an overall hypothesis of how system components interact, either directly or indirectly, through intermediate variables. Indirect effects are defined as how one variable changes another variable's influence on a third (17). A path diagram can be based on previous data, a theoretical basis, or subjective experience. Competing models are fitted, and the best fitting and parsimonious model can be selected based on an information criterion such as AIC.

Path diagrams typically include path coefficients, which are standardized partial regression coefficients ( $\beta$ weights) that indi- cate the size of direct effects of variables when other variables are held constant. The sign of the path coefficients indicates positive or negative associations among the variables. Path coefficients can be decomposed to infer direct and indirect casual effects of an "exogenous" (analogous to a predictor variable in linear regression) variable on an endogenous variable. Direct effects are obtained by multiplying path coefficients for every connecting arrow between variables and the response variable; indirect effects are calculated as the sum of these values. The total effect is the sum of the direct and indirect values (17).

Based on the predictor variables identified in the preliminary analyses and the logistic regression (described below), several structural models were built to evaluate potential paths leading to
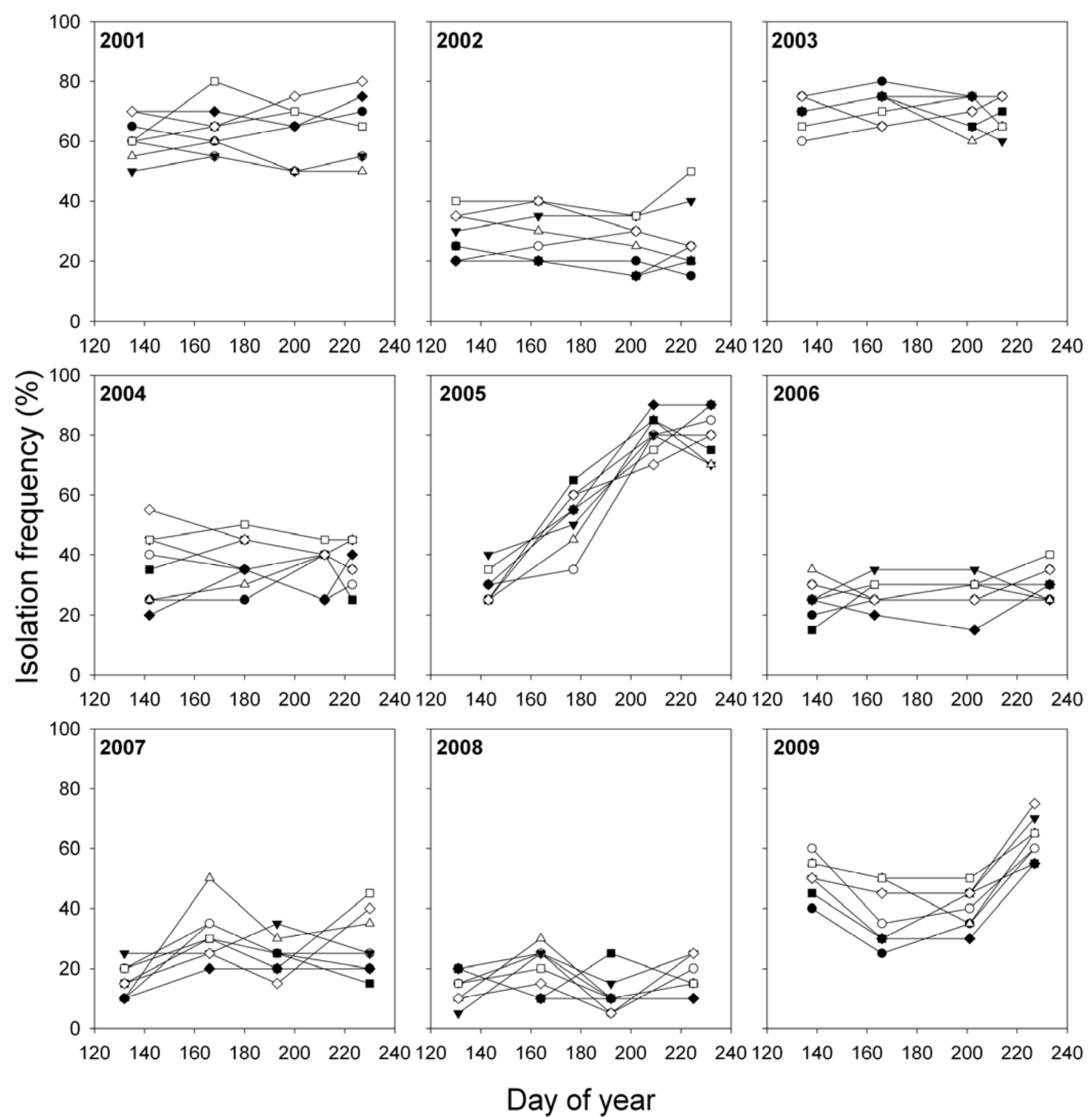

Fig. 1. Seasonal fluctuations in the isolation frequency of Phoma ligulicola var. inoxydabilis during austral autumn and winter in commercial pyrethrum fields in Tasmania, Australia. At each sampling time, 20 isolations were made from necrotic lesions on pyrethrum plants in plots that were not treated with fungicides. Eight pyrethrum production regions across northern Tasmania were sampled each year, and each production region is represented by the same symbol in every year. 

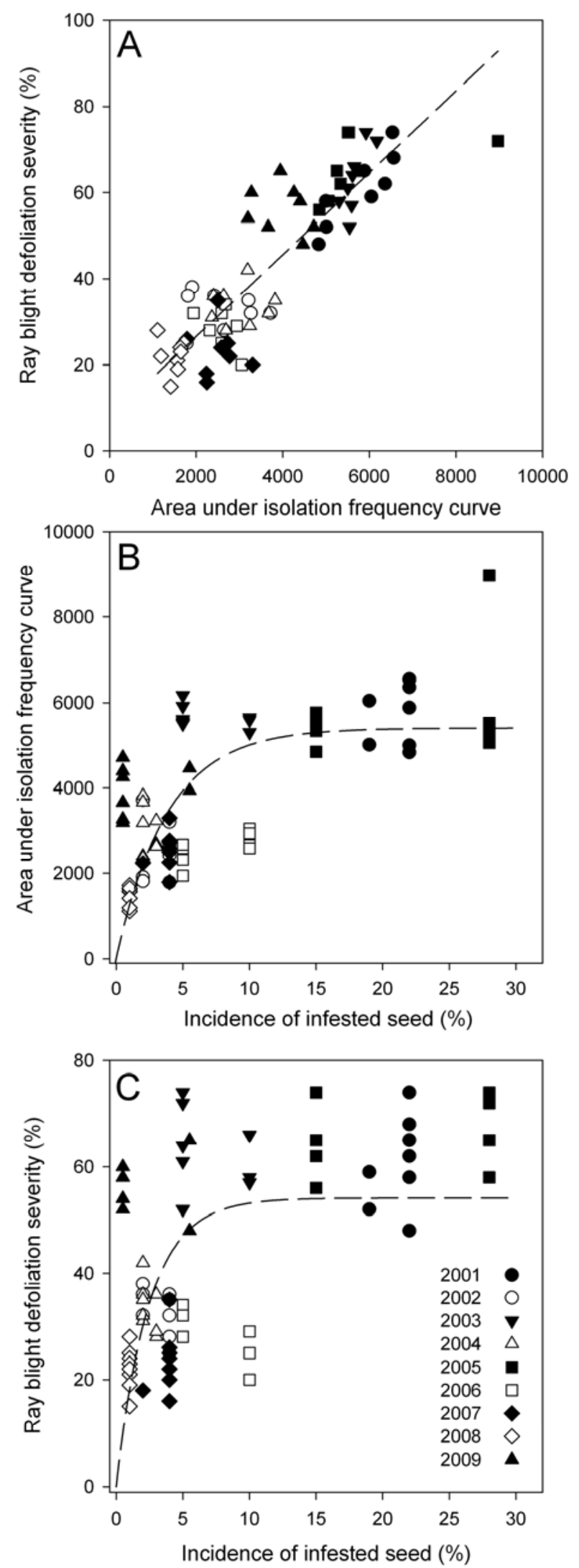

Fig. 2. Scatterplots illustrating the relationship between isolation frequency of Phoma ligulicola var. inoxydabilis, incidence of seed infestation with the pathogen, and defoliation severity due to ray blight on pyrethrum. Dashed lines are fits of $\mathbf{A}$, linear or $\mathbf{B}$ and $\mathbf{C}$, nonlinear regression with equations: $\mathbf{A}, y=$ $7.58+0.0095 x\left(R^{2}=0.78\right) ; \mathbf{B}, y=0.002579+0.000000104 \times(1-\exp (-0.261 \times$ x) $\left(R^{2}=0.50\right)$; and $\mathbf{C}, y=0.3229+0.026 \times(1-\exp (-0.005504 \times x))\left(R^{2}=\right.$ $0.35)$. Data are from non-fungicide-treated plots in 72 commercial pyrethrum fields in Tasmania, Australia, during 2001 to 2009 (eight fields per year). severity of defoliation in spring. The models were based on knowledge and logical assumptions about the disease cycle (i.e., seedborne inoculum leading to overwintering inoculum) and how weather may affect host and pathogen development. In all models, the incidence of seed infested with $P$. ligulicola was modeled to be explanatory of overwintering of the pathogen (expressed as AUIFC) which, in turn, was modeled as a cause of defoliation in spring (the "endogenous" variable in path analysis terminology). The two rain $\times$ degree-day product variables for the March-April and June-July periods were entered into the models as contributing causes of pathogen overwintering (i.e., affecting isolation frequency) or direct explanatory variables for defoliation in the spring. We evaluated models where (i) the weather variables interacted to affect overwintering isolation frequency and also defoliation directly (both indirect and direct effects), (ii) the weather variables affected overwintering isolation frequency (only indirect effects on defoliation), and (iii) the weather variables were only explanatory variables for defoliation severity (only direct effects on defoliation). The analysis was implemented in the CALIS procedure in SAS. To conduct the analysis, a correlation matrix of the variables used in the models was constructed using the CORR procedure. Path analysis assumes that variables are normally distributed and linearly related. Therefore, the incidence of infested seed was square root transformed to produce a linear relationship with defoliation severity for this analysis. Goodness-of-fit of the models was assessed with a $\chi^{2}$ test and by inspection of residual diagrams. Each model was fit separately and the model that minimized AIC was deemed the most appropriate (17). The significance of each path was assessed by $t$ tests; values $>2$ indicated significant paths $(\alpha=0.05)$. Standardized partial regression coefficients ( $\beta$ weights) and estimated direct and indirect effects were calculated as described above by SAS.

\section{RESULTS}

Seasonal fluctuations in $P$. ligulicola var. inoxydabilis isolation frequency. Substantial variation was observed in the

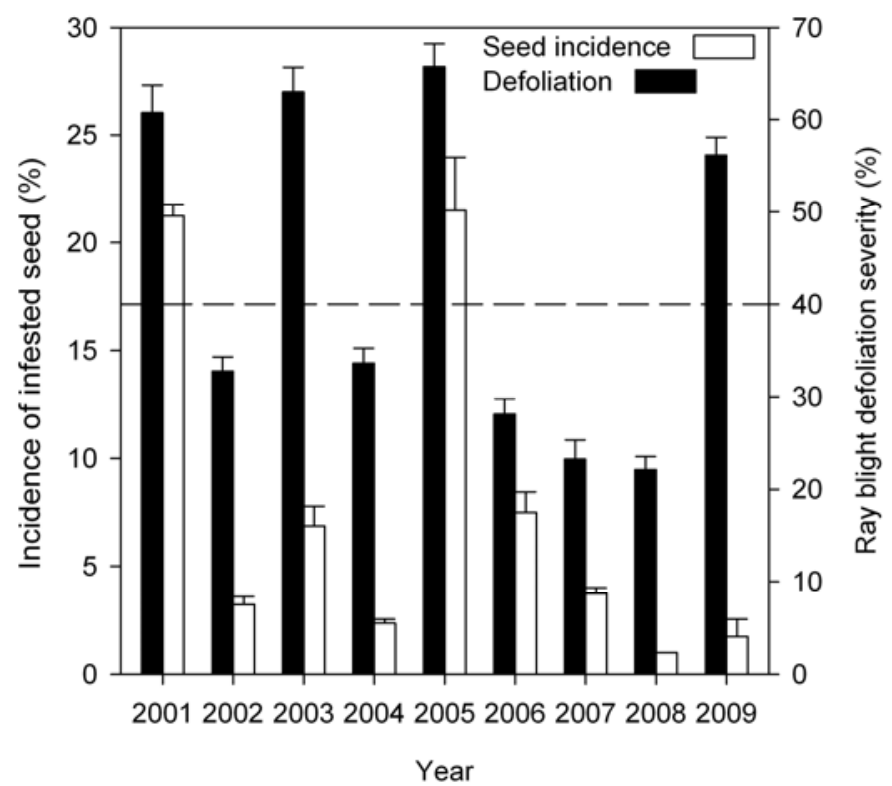

Fig. 3. Defoliation severity during regional outbreaks of ray blight of pyrethrum, caused by Phoma ligulicola var. inoxydabilis, and its association with the incidence of the causal pathogen in seed used to establish the fields. Each bar represents mean values ( \pm standard error) from plots in eight commercial pyrethrum fields that were not treated with fungicides. The dashed line at $40 \%$ defoliation severity represents the approximate economic injury level for ray blight in Tasmania, Australia (25). 
seasonal isolation frequency and trends of $P$. ligulicola var. inoxydabilis within and between years (Fig. 1). In some years, there was little increase in isolation frequency over the sampling time period (e.g., 2003) whereas, in other years (e.g., 2005), there were clear trends for increasing isolation frequency over time. When the AUIFC was calculated, the values varied as much as 2.3-fold (between 2005 and 2008).

Although there appeared to be substantial annual fluctuations in isolation frequency, within years relatively similar trends across the production regions were noted (Fig. 1). These were confirmed by a mixed-model analysis of AUIFC as a function of the factors year and region; year $(P<0.0001)$ was highly significant while region $(P=0.480)$ was not.

Preliminary analyses of variables related to overwintering inoculum and ray blight epidemics. Weather and inoculum variables associated with isolation frequency (expressed as
AUIFC) were sought to explain the seasonal variations in overwintering success of $P$. ligulicola var. inoxydabilis on pyrethrum foliage. AUIFC was significantly correlated with the amount of rain in February and March (late summer to early autumn) and May and June (winter), although the sign of the correlation depended on the month (Table 1). Thermal accumulation, expressed as degree-days, during June and July also was correlated with AUIFC (Table 1). After inspection of outliers in the scatterplots, two simple product variables were created to integrate rain and thermal units. These variables were $\log$ rain (March + April $) \times$ degree-days (March + April) and a similar product variable for June and July. Both of these new variables also were positively correlated with AUIFC ( $r=0.35$ and $P=0.003$ for March-April; $r=0.47$ and $P<0.0001$ for June-July).

With the exception of rainfall in February, variables associated with AUIFC also were associated with defoliation severity in
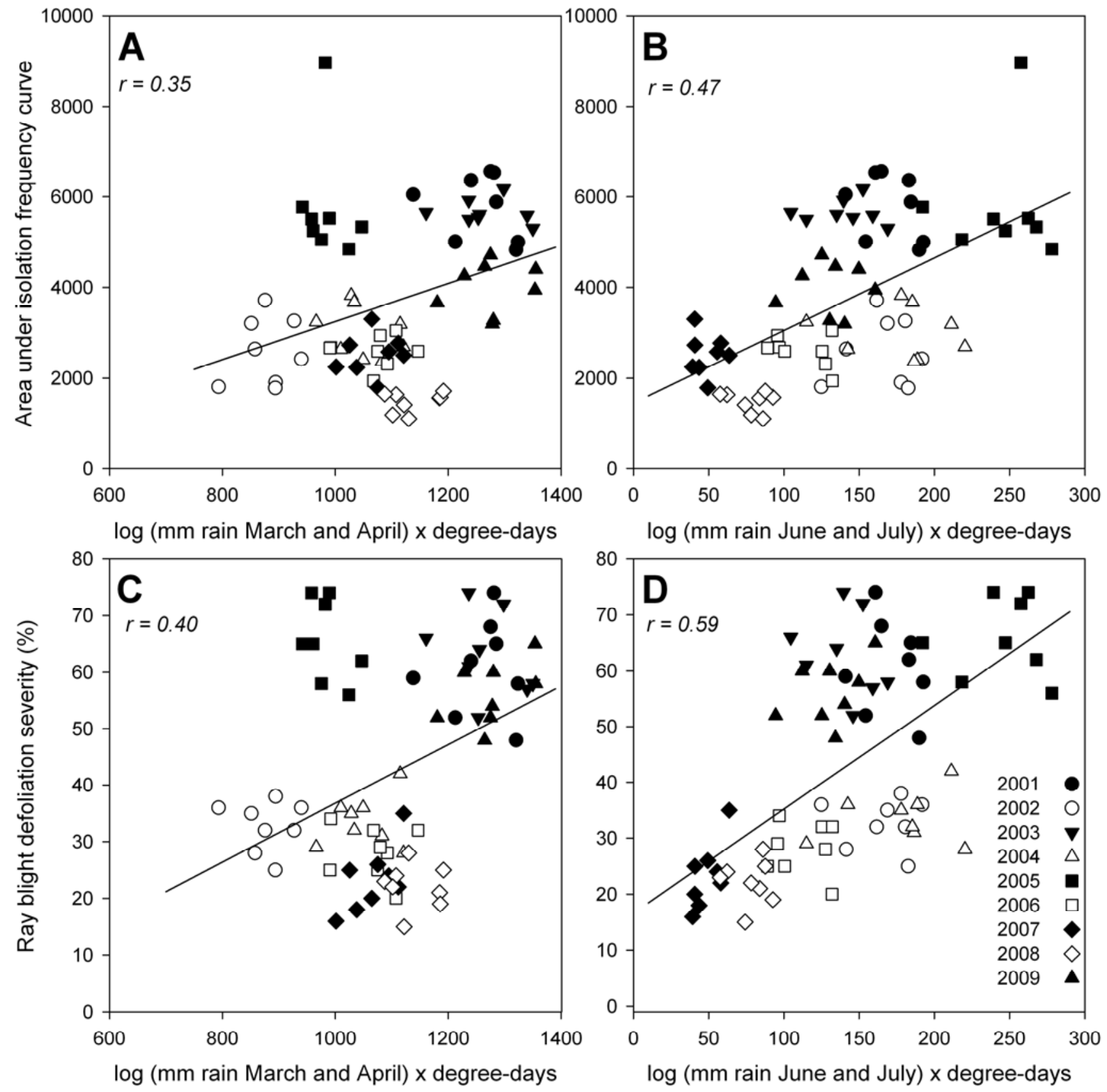

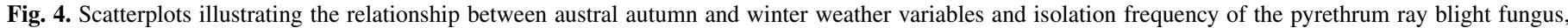

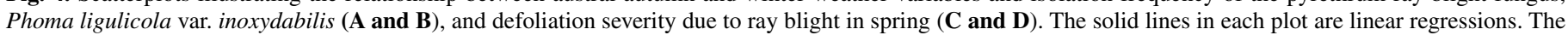
slope of all regressions is significantly greater than $0(P \leq 0.003)$. Pearson's correlation coefficient is given numerically on each graph. 
spring (Table 1). For both monthly rain and degree-days, there was a general tendency for the strength of the correlation with defoliation severity (and its significance level) to increase as the month approached the time of stem elongation in August (Table 1). Similar trends were apparent for the KS test statistic as well.

AUIFC was highly correlated with subsequent defoliation severity in spring (Fig. 2A; Table 1), with correlation coefficient $r=0.88(P<0.0001)$. Inspection of scatterplots of defoliation severity and AUIFC by years indicated substantial annual variations that were not explained solely by the weather variables investigated (Fig. 2A). AUIFC and defoliation severity were related to the incidence of seed infested with $P$. ligulicola var. inoxydabilis by a saturation-type relationship described by a three-parameter single-exponential rise to a maximum (Fig. 2B and $\mathrm{C}$ ). The equation relating AUIFC to the incidence of infested seed was $y=0.002579+0.000000104 \times[1-\exp (-0.261 \times x)]$ $\left(R^{2}=0.50\right)$, and the equation describing defoliation severity as a function of infested seed was $y=0.3229+0.026 \times[1-$ $\exp (-0.005504 \times x)]\left(R^{2}=0.35\right)$. Variation between consecutive years were similar for both variables but relationships between variables in terms of absolute values across years were very faint (Fig. 3). There were complex interrelationships among weather, overwintering inoculum, and defoliation severity (Fig. 4), and some of the weather variables associated with AUIFC and defoliation severity were also related to the incidence of infested seed (Table 1).

Logistic regression modeling of severe ray blight epidemics. Based on the analyses described above, logistic regression models were constructed to develop preharvest risk algorithms to estimate the probability of severe ray blight epidemics. Automated stepwise selection identified that AUIFC alone was a very good predictor of severe epidemics, with an area under the receiver operating characteristic curve of 0.98 (Table 2). The model predicted an increasing likelihood of severe epidemics with increasing values of AUIFC that closely mirrored the observed epidemic severity (Fig. 5A). Assuming a nominal threshold probability of 0.5 (corresponding to an AUIFC of 3603.7) for classifying a given data set as a severe versus nonsevere epidemic, the model had $92 \%$ accuracy, $91 \%$ sensitivity, and $92 \%$ specificity. The fit of the model was adequate based on the Hosmer-Lemeshow test $(P=0.96)$.

The second model fit without AUIFC as a predictor had similar predictive ability. This model had three predicator variables: incidence of infested seed, log (rain) $\times$ degree-days in MarchApril, and $\log$ (rain) $\times$ degree-days in June-July (Table 2). When

TABLE 2. Logistic regression parameter estimates and significance tests for models estimating the probability of a severe spring epidemic of ray blight (caused by Phoma ligulicola var. inoxydabilis) on pyrethrum

\begin{tabular}{|c|c|c|c|c|c|}
\hline \multirow[b]{2}{*}{ Parameter $^{\mathrm{a}}$} & \multicolumn{4}{|c|}{ Analysis of maximum likelihood estimates } & \multirow[b]{2}{*}{ AUROC } \\
\hline & Estimate & Standard error & Wald $\chi^{2}$ & $P$ value & \\
\hline \multicolumn{6}{|c|}{ Model including isolation frequency of pathogen } \\
\hline Intercept & -13.045 & 3.819 & 11.724 & 0.001 & 0.984 \\
\hline \multicolumn{6}{|c|}{ Model excluding isolation frequency of pathogen } \\
\hline Intercept & -51.441 & 17.082 & 9.069 & 0.003 & 0.988 \\
\hline Seed infestation & 0.620 & 0.225 & 7.591 & 0.006 & $\ldots$ \\
\hline
\end{tabular}

${ }^{a}$ Data for fitting the models were obtained from non-fungicide-treated plots in 72 commercial pyrethrum fields in Tasmania, Australia during 2001 to 2009 (eight fields per year). Severe outbreaks were considered those that caused at least $40 \%$ defoliation severity based on previous research (25).

${ }^{\mathrm{b}}$ Area under the receiver operating characteristic curve (AUROC) is an overall measure of classification accuracy.
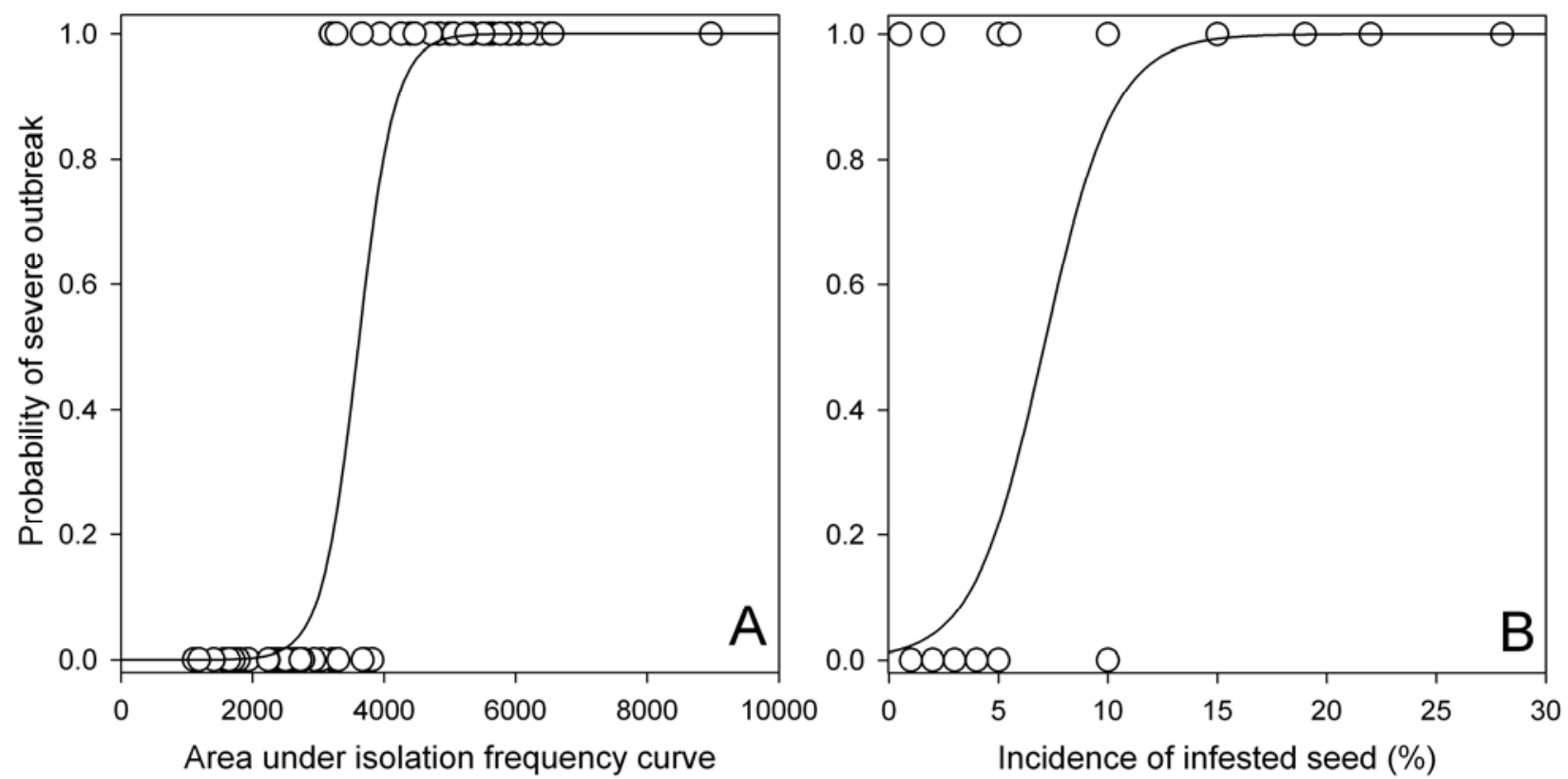

Fig. 5. Estimated probability of a severe spring epidemic of ray blight of pyrethrum (caused by Phoma ligulicola var. inoxydabilis) based on the logistic models presented in Table 2. A, Severe epidemics were modeled to be related solely to the isolation frequency of the pathogen during autumn and winter. B, Model includes explanatory variables of incidence of infested seed and $\log ($ rain $) \times$ degree-days (base $5^{\circ} \mathrm{C}$ ) in March-April and June-July. Values of the weather variables used in the calculations in B were mean values observed during 2001 to 2009 across the eight pyrethrum production regions included in this study $(n=72$ fields). Open circles indicate the observed epidemic severity. A value of 1 indicates a severe epidemic and 0 is a nonsevere epidemic. 
values of the weather variables were set to the mean values observed over the 72 fields used for model development $(1,110$ for March-April and 1,025 for June-July), the model predicted increasing likelihood of severe outbreaks with increasing incidence of infested seed (Fig. 5B). Overall predictive ability was similar based on area under the receiver operating characteristic curve (0.99) and accuracy of $92 \%$. Sensitivity of this model was $88 \%$ and specificity was $95 \%$. The Hosmer-Lemeshow goodnessof-fit test again indicated an adequate fit $(P=0.99)$.

Path analysis. The predictor variables selected in the logistic regression analysis were evaluated in three different path dia- grams leading to defoliation severity. Only the first model (Fig. 6A) had an adequate fit based on a $\chi^{2}$ goodness-of-fit test $(P=$ $0.425)$. Within each path diagram, all paths were significant based on $t$ tests (Fig. 6, values presented parenthetically). In each of the three models, the largest path coefficients (and $t$ statistics) were associated with seed infestation effects on AUIFC and AUIFC effects on defoliation severity. The first model provided the best fit, based on minimizing AIC, which assumed direct effects of the weather variables $\log$ (rain) $\times$ degree-days in March-April and $\log$ (rain) $\times$ degree-days in June-July on defoliation severity, and indirect effects of these weather variables on defoliation through

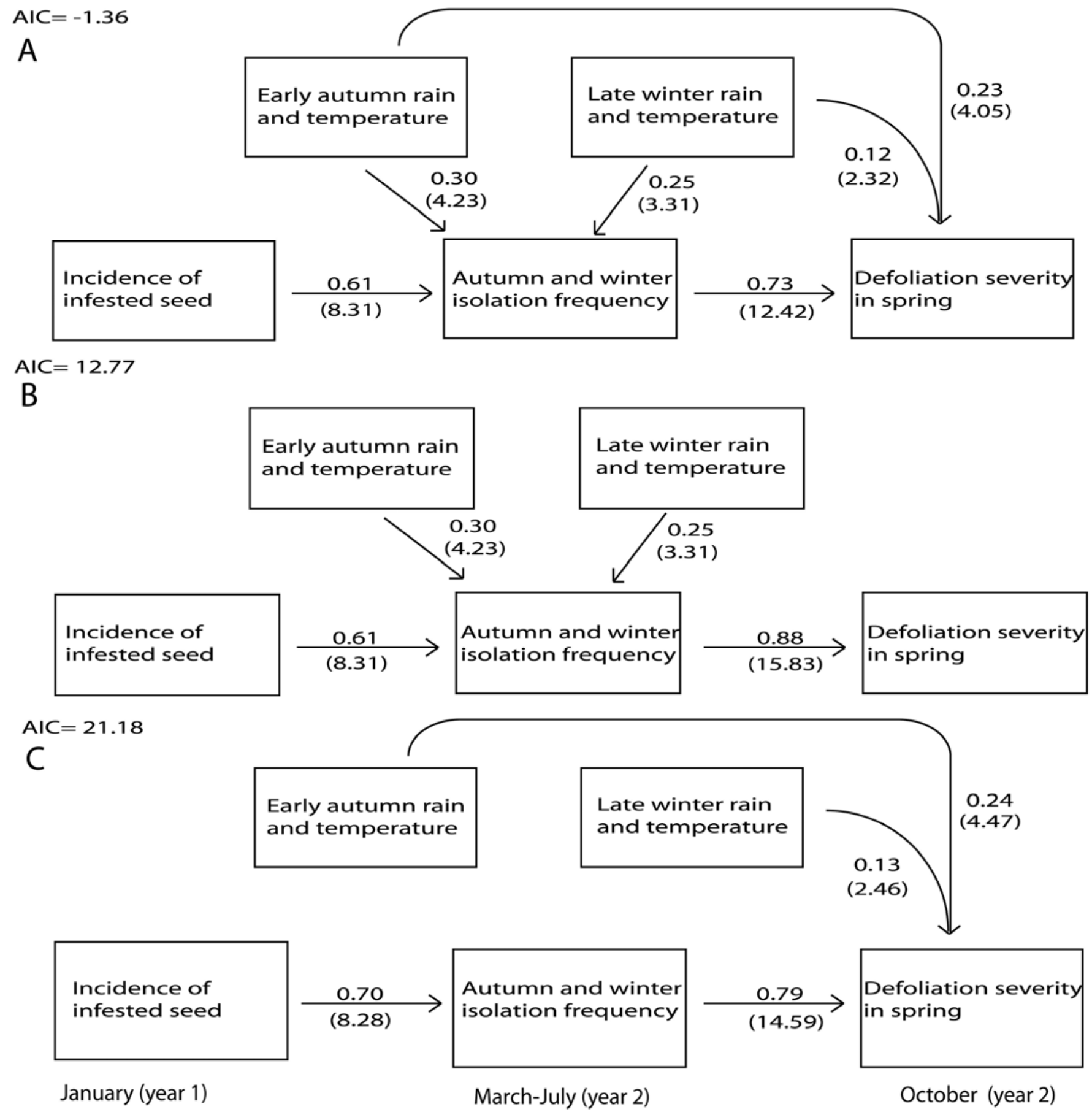

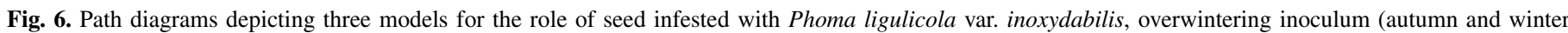

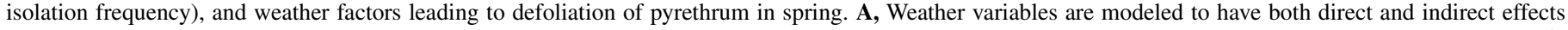

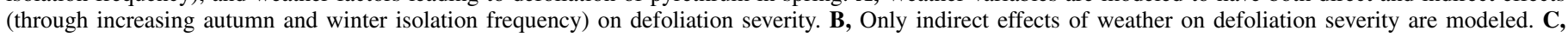

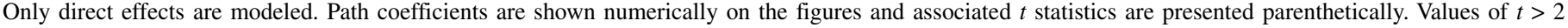

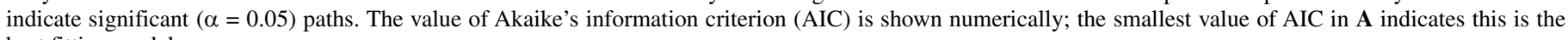
best fitting model. 
increasing AUIFC (Fig. 6A). The model assuming weather only directly affecting defoliation severity had the poorest fit based on AIC (Fig. 6C).

For the best-fitting model, the effect of infested seed on defoliation severity was entirely indirect through increasing AUIFC (Table 3). Weather factors in autumn (March-April) and winter (June-July) had indirect effects on defoliation severity through increasing AUIFC, although these effects were smaller than that of infested seed. The model also indicated that the weather variables for both March-April and June-July had significant direct effects on defoliation severity not mediated by increasing AUIFC.

\section{DISCUSSION}

This study has clearly demonstrated that, over the last 9 years, the amount of overwintering inoculum of $P$. ligulicola var. inoxydabilis in the form of necrotic lesions on pyrethrum leaves in Australian fields has a direct association with the severity of defoliation during the spring epidemic phase of the disease. In turn, the amount of overwintering inoculum, as measured by the AUIFC, was directly affected by rainfall and thermal accumulation in early autumn and late winter, which affected both the AUIFC and defoliation severity. However, the most significant factor affecting both AUIFC and defoliation severity (indirectly) was the incidence of $P$. ligulicola var. inoxydabilis infestation in seed. The relationship between defoliation severity and the resultant incidence of the pathogen in the harvested seed has been shown to be linear (32). In a sense, then, environmental conditions in the spring prior to harvest of seed crops are also indirectly related to the severity of ray blight epidemics some 18 to 24 months later in fields approaching their first harvest. Pyrethrum seed is typically harvested in late summer (February), and is then used as the source of planting material in the subsequent late winter (August). In this study, it is clear that seed is a key risk factor for initiating regional ray blight epidemics.

Additional evidence also strongly supports these findings. Population genetic analysis of seedborne pathogens can provide insights into routes of dissemination in seed, based on interstate or national movement of pathogens (1). Previous studies of the population structure of $P$. ligulicola var. inoxydabilis indicated

TABLE 3. Direct and indirect effects of inoculum and weather variables on defoliation severity of pyrethrum caused by ray blight, as derived by path analysis $^{\mathrm{a}}$

\begin{tabular}{|c|c|c|c|c|}
\hline \multirow[b]{2}{*}{ Variable } & \multirow{2}{*}{$\begin{array}{c}\text { Infested } \\
\text { seed }^{\mathrm{b}}\end{array}$} & \multicolumn{2}{|c|}{ Weather variables ${ }^{\mathrm{c}}$} & \multirow[b]{2}{*}{ AUIFC $^{d}$} \\
\hline & & March-April & June-July & \\
\hline \multicolumn{5}{|l|}{ Total effect } \\
\hline AUIFC & 0.614 & 0.299 & 0.246 & 0 \\
\hline Defoliation severity & 0.451 & 0.341 & 0.407 & 0.734 \\
\hline \multicolumn{5}{|l|}{ Indirect effect } \\
\hline Defoliation severity & 0.451 & 0.220 & 0.181 & 0 \\
\hline
\end{tabular}

a See Figure 6A for the corresponding path diagram. Direct effects are obtained by multiplying path coefficients for every connecting arrow between variables and the response variable; indirect effects are calculated as the sum of these values. Total effect is the sum of the direct and indirect values (18).

${ }^{\mathrm{b}}$ Seed infestation is the incidence of Phoma ligulicola var. inoxydabilis in seed used to establish a field.

${ }^{\mathrm{c}}$ Weather variables for each 2-month period were $\log$ rain $\times$ accumulated degree-days for the same period. Simple degree-days were calculated as (daily high temperature + daily low temperature) $/ 2-5^{\circ} \mathrm{C}$.

$\mathrm{d}$ AUIFC $=$ area under isolation frequency curve for P. ligulicola var. inoxydabilis. At each of the four sampling time points per year, 20 isolations were made from necrotic lesions on pyrethrum grown in plots that were not treated with fungicides. Eight pyrethrum production regions across northern Tasmania were sampled each year during 2001 to $2009(n=72$ fields in total).

${ }^{\mathrm{e}}$ Defoliation severity due to ray blight was assessed in spring (October) in the same plots where the isolations were made previously. that the fungus is mostly clonal in pyrethrum fields (16). Currently, pyrethrum seed is produced from a small number of crops located in northern Tasmania surrounded by the main pyrethrum production regions. The clonal genetic structure of the fungus also points to a localized, homogeneous source of primary inoculum from the few seed crops.

Based on temporal analyses (26), ray blight was predicted to be polycyclic in the period of rapid pyrethrum stem elongation in spring, which coincides with the time stems are believed to be the most susceptible to infection. Given the key role of initial inoculum as infested seed in epidemic development, the disease cycle for ray blight has elements that are characteristic of a monocylic disease in nature or a polycyclic disease with very short epidemic duration (20). The varied temporal progression of ray blight depending on the time course of observations (e.g., spring only versus the overwintering phases) underscores the need for careful interpretation of disease progress curves for inferring the disease cycle, as articulated previously (36).

In a separate investigation of temporal patterns of defoliation severity in 11 of the fields included in this study during 2003 to 2005, when the fields progressed from first to third harvest, ray blight defoliation severity in October declined with field age (S. J. Pethybridge, unpublished data). This indicates that polyetic epidemics of ray blight appear rare. Many examples of polyetic epidemic behavior can be found in other perennial hosts affected by pathogens with a foliar phase $(6,9,13)$. The close linkage of seedborne inoculum to ray blight epidemics in first-harvest pyrethrum fields and the insufficient evidence for polyetic epidemic behavior in subsequent harvests is notable. Substantial decline in plant density typically is observed in pyrethrum following first harvest (30). A decrease in plant density would generally reduce the conduciveness of microclimatic conditions for $P$. ligulicola var. inoxydabilis, reducing the number of infection events occurring throughout autumn and winter and, in turn, AUIFC and defoliation severity in the subsequent years. Therefore, the inherent agronomic traits of the production system may be driving epidemic behavior in a monocyclic-type fashion, counterintuitively to what may be expected by a foliar pathogen on a perennial host (20).

Path analysis, which has found some use in botanical epidemiology $(18,37,38)$, was a useful tool to assist in quantifying the interrelationships among the set of variables associated with ray blight defoliation severity. The analysis points to two obvious areas for interrupting the disease cycle: reduction of primary inoculum in seed and reduction of overwintering success of the fungus. Although the process of seed-to-seedling transmission of $P$. ligulicola var. inoxydabilis is largely unknown, a linear relationship has been characterized between the severity of ray blight and resultant incidence of the pathogen in seed (32). Factors that reduce ray blight such as dry growing conditions (27), site selection (28), and chemical control measures $(31,33)$ are also expected to reduce seedborne inoculum levels. Management of the overwintering phase of ray blight, which is not currently routine, is an unexplored area for potential mitigation of the disease. Based on the logistic regression models developed in this research, both strategies would be predicted to substantially reduce the likelihood of severe outbreaks of ray blight.

\section{ACKNOWLEDGMENTS}

This project was funded in part by Horticulture Australia Limited (project number PY09002), Botanical Resources Australia-Agricultural Services Pty. Ltd., and the United States Department of AgricultureAgricultural Research Service CRIS Project 5358-21000-050-00. Travel of Dr. Gent to Australia was funded by the Australian Research CouncilLinkage program (LP100100529). We thank. J. Scott, University of Tasmania, and J. Woods, Oregon State University, for their helpful review of an earlier draft of this manuscript. 


\section{LITERATURE CITED}

1. Atallah, Z. K., Maruthachalam, K., du Toit, L., Koike, S. T., Davis, R. M., Klosterman, S. J., Hayes, R. J., and Subbarao, K. V. 2010. Population analyses of the vascular plant pathogen Verticillium dahliae detect recombination and transcontinental gene flow. Fungal Genet. Biol. 47:416-422.

2. Aveskamp, M. M., de Gruyter, J., Woudenberg, J. H. C., Verkley, G. J. M., and Crous, P. W. 2010. Highlights of the Didymellaceae: A polyphasic approach to characterise Phoma and related Pleosporalean genera. Stud. Mycol. 65:1-60.

3. Baker, K. F., and Davis, L. H. 1959. Ascochyta disease of chrysanthemum appears in California. Calif. State Florists Assoc. Mag. 8:A-B.

4. Baker, K. F., Dimock, A. W., and Davis, L. H. 1949. Life history and control of the Ascochyta ray blight of chrysanthemum. Phytopathology 39:789-805.

5. Baker, K. F., Dimock, A. W., and Davis, L. H. 1961. Cause and prevention of the rapid spread of the Ascochyta disease of chrysanthemum. Phytopathology 51:96-101.

6. Behlau, F., Amorim, L., Belasque, J., Bergamin Filho, A., Leite, R. P., Graham, J. H., and Gottwald, T. R. 2010. Annual and polyetic progression of citrus canker on trees protected with copper sprays. Plant Pathol. 59:1031-1036.

7. Brown, P. H., and Menary, R. C. 1994. Flowering in pyrethrum (Tanacetum cinerariaefolium L.). 1. Environmental requirements. J. Hortic. Sci. 69:877-884.

8. de Gruyter, J., Boerema, G. H., and van der Aa, H. A. 2002. Contributions towards a monograph of Phoma (Coelomycetes) VI-2 - Section Phyllostictoides: Outline of its taxa. Persoonia 18:1-52.

9. Gent, D. H., Ocamb, C. M., and Farnsworth, J. L. 2010. Forecasting and management of hop downy mildew. Plant Dis. 94:425-431.

10. Huber, L., and Gillespie, T. J. 1992. Modeling leaf wetness in relation to plant disease epidemiology. Annu. Rev. Phytopathol. 30:553-577.

11. Hutchinson, M. F. 1995. Interpolating mean rainfall using thin plate smoothing splines. Int. J. Geogr. Inf. Syst. 9:385-403.

12. Jeffrey, S. J., Carter, J. O., Moodie, K. M., and Beswick, A. R. 2001. Using spatial interpolation to construct a comprehensive archive of Australian climate data. Environ. Model. Softw. 16/4:309-330.

13. Johnson, D. A., and Anliker, W. L. 1985. Effect of downy mildew epidemics on the seasonal carryover of initial inoculum in hop yards. Plant Dis. 69:140-142.

14. Jones, A. L. 1986. Role of wet periods in predicting foliar diseases. Pages 87-100 in: Plant Disease Epidemiology: Population Dynamics and Management. K. J. Leonard and W. E. Fry, eds. Macmillan, New York.

15. Jones, S., Pethybridge S. J., Hay, F. S., Groom, T., and Wilson, C. R. 2007. Baseline sensitivity of Australian Phoma ligulicola isolates from pyrethrum to azoxystrobin and difenoconazole. J. Phytopathol. 155:377380.

16. Latham, R., and Pethybridge, S. J. 2005. Genetic variability of Phoma ligulicola in Tasmania, Australia. (Abstr.) Phytopathology 95:964.

17. Loehlin, J. C. 1987. Latent Variable Models, An Introduction to Factor, Path, and Structural Analysis. Lawrence Erlbaum Associates, Hillsdale, NJ.

18. Lundquist, J. E. 2007. The relative influence of diseases and other smallscale disturbances on fuel loading in the Black Hills. Plant Dis. 91:147152.

19. MacDonald, W. L. 1995. Pyrethrum flowers-production in Australia. Pages 55-66 in: Pyrethrum Flowers: Chemistry, Toxicology and Uses. J. E. Casida and G. B. Quistad, eds. Oxford University Press, New York.

20. Madden, L. V., Hughes, G., and van den Bosch, F. 2007. The Study of
Plant Disease Epidemics. American Phytopathological Society, St. Paul, MN.

21. McCoy, R. E. 1971. Epidemiology of chrysanthemum Ascochyta blight. Ph.D. diss. Cornell University, Ithaca, NY.

22. McCoy, R. E., and Dimock, A. W. 1973. Environmental factors regulating ascospore discharge by Mycosphaerella ligulicola. Phytopathology 63:586-589.

23. McCoy, R. E., Horst, R. K., and Dimock, A. W. 1972. Environmental factors regulating sexual and asexual regulation by Mycosphaerella ligulicola. Phytopathology 62:1188-1195.

24. Morrison, D. F. 1976. Multivariate Statistical Methods. McGraw-Hill, New York.

25. Pethybridge, S. J., Esker, P. D., Dixon, P., Hay, F. S, Groom, T., Wilson, C. R., and Nutter, F. W., Jr. 2007. Quantifying loss caused by ray blight disease in Tasmanian pyrethrum fields. Plant Dis. 91:1116-1121.

26. Pethybridge S. J., Esker, P. D., Hay, F. S., Wilson, C. R., and Nutter, F. W., Jr. 2005. Spatiotemporal description of epidemics caused by Phoma ligulicola in Tasmanian pyrethrum fields. Phytopathology 95:648-658.

27. Pethybridge, S. J., Gent, D. H., Esker, P. D., Turechek, W. W., Hay, F. S., and Nutter, F. W., Jr. 2009. Site-specific risk factors for ray blight in Tasmanian pyrethrum fields. Plant Dis. 93:229-237.

28. Pethybridge, S. J., and Hay, F. S. 2001. Influence of Phoma ligulicola on yield and site factors on disease development in Tasmanian pyrethrum crops. Aust. Plant Pathol. 30:17-20.

29. Pethybridge, S. J., Hay, F. S., Esker, P. D., Gent, D. H., Wilson, C. R., and Nutter, F. W., Jr. 2008. Diseases of pyrethrum in Tasmania: challenges and prospects for management. Plant Dis. 92:1260-1272.

30. Pethybridge, S. J., Hay, F. S., and Groom, T. 2003. Seasonal fluctuations in fungi associated with pyrethrum foliage in Tasmania. Aust. Plant Pathol. 32:223-230.

31. Pethybridge, S. J., Hay, F. S., Groom, T., and Wilson, C. R. 2008. Improving fungicide-based management of ray blight disease in Tasmanian pyrethrum fields. Plant Dis. 92:887-895.

32. Pethybridge, S. J., Hay, F. S., Jones, S. J., Wilson, C. R., and Groom, T. 2006. Seedborne infection of pyrethrum by Phoma ligulicola. Plant Dis. 90:891-897.

33. Pethybridge, S. J., Hay, F. S., Wilson, C. R., and Groom, T. 2005. Development of a fungicide-based management strategy for foliar disease caused by Phoma ligulicola in Tasmanian pyrethrum fields. Plant Dis. 89:1114-1120.

34. Pethybridge, S. J., Ngugi, H. K., and Hay, F. S. 2010. Use of survival analysis to assess management options for ray blight in Australian pyrethrum fields. Plant Pathol. 59:480-491.

35. Pethybridge, S. J., and Wilson, C. R. 1998. Confirmation of ray blight disease of pyrethrum in Australia. Aust. Plant Pathol. 27:45-48.

36. Pfender, W. F. 1982. Monocyclic and polycyclic root diseases-distinguishing between the nature of the disease cycle and the shape of disease progress curve. Phytopathology 72:31-32.

37. Ristaino, J. B., and Averre, C. W. 1992. Effects of irrigation, sulfur, and fumigation on Streptomyces soil rot and yield components in sweet potato. Phytopathology 82:670-677.

38. Savary, S., Castilla, N. P., Elazegui, F. A., McLaren, C. G., Ynalvez, M. A., and Teng, P. S. 1995. Direct and indirect effects of nitrogen supply and disease source structure on rice sheath blight spread. Phytopathology 85:959-965.

39. Stone, R. C., Hammer, G. L., and Marcussen, T. 1996. Prediction of global rainfall probabilities using phases of the Southern Oscillation Index. Nature 384:252-255.

40. van der Aa, H. A., Noordeloos, M. E., and de Gruyter, J. 1990. Species concepts in some larger genera of the Coelomycetes. Stud. Mycol. 32:3-19. 